Revue Française de Civilisation Britannique

\title{
Introduction: Seventy Years On: Framing Health Policy in Britain
}

Soixante-dix ans après la création du NHS: Quelles politiques de santé publique?

Louise Dalingwater

\section{OpenEdition}

Journals

Electronic version

URL: http://journals.openedition.org/rfcb/4128

DOI: $10.4000 /$ rfcb. 4128

ISSN: 2429-4373

Publisher

CRECIB - Centre de recherche et d'études en civilisation britannique

Electronic reference

Louise Dalingwater, «Introduction: Seventy Years On: Framing Health Policy in Britain », Revue

Française de Civilisation Britannique [Online], XXIV-3 | 2019, Online since 30 August 2019, connection on 04 September 2019. URL : http://journals.openedition.org/rfcb/4128; DOI : 10.4000/rfcb.4128

This text was automatically generated on 4 September 2019

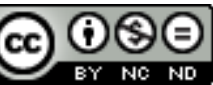

Revue française de civilisation britannique est mis à disposition selon les termes de la licence Creative Commons Attribution - Pas d'Utilisation Commerciale - Pas de Modification 4.0 International. 


\title{
Introduction: Seventy Years On: Framing Health Policy in Britain
}

Soixante-dix ans après la création du NHS : Quelles politiques de santé publique?

\author{
Louise Dalingwater
}

1 The National Health Service (NHS) turned 70 in 2018 and, to mark the event, this special issue wishes to pay tribute to an organisation and to its workers (doctors, nurses, and administrators) who provide health care to the British population. The institution still promises to provide services free at the point of use from "the cradle to the grave". It is one of the largest employers in Europe, with over one million staff. The NHS is considered essential as it not only provides health care services to the British population but also aims to ensure social cohesion and a robust workforce. Public support for the NHS is strong because the British believe resolutely in universal access to health care. Indeed, according to a survey by the think tank, The Kings Fund, 90\% of those polled in 2017 stated that the founding principles of the NHS to provide health services free at the point of use should be upheld ${ }^{1}$. Recent Ipsos polls have reported similar results.

But the NHS has experienced a turbulent life since its inception. Public health care is very costly to deliver. British hospitals and public health institutions have been facing a significant cash crisis for years, which has led to debates on how much longer such a funding model can survive. The nature and scope of the work of the NHS has been transformed from ensuring post-war men were fit for work and combating infectious diseases to coping with ageing populations and long-term illnesses. Moreover, the reconfiguration of the NHS by successive governments, the changing nature of demand for health care and the shifting focus has meant that public health services are no longer considered from a purely "public good" perspective. Financial pressures, the redefinition of health and social care and globalisation have transformed the public health sector.

The National Health Service alone can no longer manage the health of the population. It is thus important to consider the provision of public health services and policy which goes beyond the scope of the NHS but has a significant impact on public health. Moreover, taking a wider perspective on public health, beyond the remit of the NHS, is 
essential because other areas related to health such as employment, income, and housing can have a significant impact on the health of the population. In recent years, health policy has also been conceptualised to mean much more than curing disease, but also enabling people to attain the highest degree of health and wellness. In light of the changing face of the NHS, this special issue seeks not only to reflect on the 70 years of the institution but also consider new and emerging trends in health care provision.

In this special issue, Powell maps the issues that the NHS has faced since its inception by examining the presentation of the NHS in political debates of the House of Commons. In keeping with the theme of this special issue, his article focuses on broad debates on each anniversary of the NHS. Apart from the $10^{\text {th }}$ anniversary, these anniversary debates have been largely neglected, perhaps because the 1958 debate was the only Commons debate there has ever been to mark an anniversary. He concludes that the view 'plus ça change' ought to be nuanced, but he does agree that old arguments have certainly not gone away or been resolved. Factors such as the longstanding pressures of medical technology, ageing populations and rising expectations, the question of whether the NHS has delivered enough for all the extra spending... have indeed marked every anniversary. Many of the problems seem to be hardy perennials whether it be finance, demography, technology, waiting lists, staff shortages, staff morale or reorganisation. While most anniversaries have been the occasion to discuss most of the themes, their salience has nevertheless tended to vary over time.

5 Barrett also takes a historical approach in her analysis of the NHS looking specifically at Child and Adolescent Mental Health Services (CAMHS) before and since the inception of the NHS. She demonstrates how the creation of a specific child and adolescent mental health service within the NHS was influenced by a number of factors including changes in adult mental health policies, the evolution of society's attitudes towards children and parenting, and a greater biological and psychological understanding of how children develop. She describes the care for young people with mental health problems in the early years of the NHS and the split between child guidance clinics and hospitals. She contends that while a single unified service was created in 1987, national guidelines for its organisation were only introduced in 1995 and these guidelines were not necessarily implemented in the same way across the country. She concludes that while there has been considerable progress in the services available for mentally unwell children and teenagers over the past seventy years, nationwide availability of high-quality, effective care for those children and adolescents suffering from severe and complex mental health problems still does not live up to ambitions to provide physical and mental health services on an equal footing.

6 Campbell and Lee show how while the NHS may still ensure free health care to the population, the health of the nation still remains vulnerable to the commercial interests of powerful actors such as corporations and industry. Their contribution underlines how such industries may actually impede or curtail health policy and preventative health measures in the community. In particular alcohol and tobacco industries manage to fight public health policies aimed at curbing alcohol and tobacco consumption by publishing poor science, political lobbying and through legal action at national and international levels. So while the NHS and local authorities may work towards better public health and health care, the authors provide evidence to show that better public health cannot be achieved solely through the promotion of healthy behaviour, but also requires active efforts to counter those powerful entities with vested interests in commercial profit. The 
manner in which the British government's commitment to introducing a minimum unit price (MUP) for alcohol in England and Wales saw an extraordinary U-turn has been described as a cautionary tale of the power of the alcohol industry to influence public health policy.

7 Porion's paper looks at a controversial figure in history, Enoch Powell, who was appointed health minister in 1960 under Harold Macmillan's Conservative government. Porion underlines how Powell's stance on the NHS and health policy was somewhat at odds with his supposed political values. While his aim was to rationalise spending in the NHS, he also wished to modernise and humanise this public health institution in the Disraeli tradition. He led an ambitious project of hospital building among other things. Such investment in the public good stood in sharp contrast with his overall hard right approach to spending and public intervention. The author analyses Powell's iconoclastic approach by using primary sources from Kew's national archives and Powell Papers from Cambridge. In order to enhance historiographical debates, his analysis focuses on three main issues: Powell's handling of the cost of drugs, cigarette advertising and the fluoridation of water. This leads onto an additional dilemma that Powell had to face on how to maintain freedom of choice in a public health service where the State was the main driver.

8 Camp's contribution reminds us that we should not consider the NHS as one single institution but also consider how each country of the United Kingdom differs in the way it provides public health services. She underlines how the provision of public health has changed quite significantly and especially since the devolution of powers to the separate regions of the UK. She focuses specifically on the Scottish case. She contends that, since 1999, Scotland's Parliament and government have striven to improve the health of the Scottish people by restoring a public service based on co-operation and not on competition, while devising policies aimed at modifying the behaviour of individuals. She concludes that while some success has been achieved thanks to the devolution of powers, political issues have somewhat clouded effective attempts to solve the health issues of the Scottish population. Moreover, tensions have been fuelled by tighter budgetary constraints and constitutional upheavals.

9 Dalingwater and Chamekh's contributions turn to some emerging trends in health and wellness. Dalingwater discusses the recent focus on person or patient-centred care in the NHS and the different methods currently in place to actively encourage patients to judge the provision of health by sharing their experiences of care and treatment, completing surveys, etc. Yet information and other data on user experiences are not currently well aggregated or used to drive improvements in health care delivery. So while the right to reply from the patient's perspective might be a way to improve care, this paper underlines a number of difficulties in collating and effectively using such information. It draws on a case study of Stafford Hospital and its failure to provide adequate care to its patients. This study shows how important it is to monitor quality care not only from external sources but from internal sources, especially patients and family. However, the conclusions are stark: a really effective nationwide system whereby staff and patients can freely air their views without fear of reprisal still has a long way to go.

Chamekh's article underlines the potential of seaside resorts to improve health and wellness. His study of Skegness as a seaside resort across the ages demonstrates how the use of seawaters to treat diseases contributed to the rise of seaside resorts. He explores the potential of resurrecting them as wellness destinations and fulfilling the wider health 
policy objectives of improving the nation's health, wellness and happiness. Chamekh essentially calls on policy makers to take a lesson from the past when the importance of seaside resorts for better health was partly driven by increasingly stressful lifestyles and the recognition that climate can contribute to improved health and wellbeing. He reminds us that this tendency was strengthened by an all-inclusive health strategy adopted by the Ministry of Health in 1919 which sought to combine preventative medicine, lifestyles, and better health care provisions to improve the health of British citizens. While preventative policy is no longer the remit of the NHS, Chamekh underlines that the government's new health strategy which seeks to prevent the physical and mental problems of an ageing population could avoid hospitalisation and reduce the burden on the NHS. Health policy makers should thus encourage the British population to seek the sea air to ensure good physical and mental health.

11 Finally Holdsworth contrasts the UK and US health care systems. Both countries are working to decrease wasteful spending. The United States wastes money in its unnecessarily high use of testing and procedures and through its volatile prices that affect how health services are managed. Administrative costs in the US are also high, due to its relatively un-regulated complex system. The UK, on the other hand, spends less percapita on health with verifiably better outcomes. However, both countries need to monitor more carefully forms of wasteful spending. In the US, the government needs to follow the Choosing Wisely recommendations more carefully to reduce certain practices that physicians claim do not produce sufficient benefits. The UK, as it moves past 70 years, needs to support accountable care and integrated budgets to maximize the population health benefit of limited investment. The author concludes by underlining that at a time when prices continue to rise, the population is ageing and chronic diseases are preventing a part of the population from living life to the full, it is essential that health care systems address wasteful spending and strive to produce the equitable care and services that people deserve.

This issue has been prepared and stylized for online publication with the LODEL software programme by John Mullen and Arnaud Page.

\section{NOTES}

1. https://www.kingsfund.org.uk/publications/what-does-public-think-about-nhs 


\section{AUTHOR}

LOUISE DALINGWATER

HDEA, Sorbonne-université, Paris 